\title{
Factors Affecting Stock Return of Manufacturing Companies in Indonesia
}

\author{
Henny Setyo Lestari \\ Faculty of Economics and Business \\ Universitas Trisakti Jakarta, Indonesia \\ henny_setyo_lestari@trisakti.ac.id
}

\author{
Bahtiar Usman \\ Faculty of Economics and Business \\ Universitas Trisakti Jakarta, Indonesia \\ Bachtiar.usman@trisakti.ac.id
}

\begin{abstract}
This study aims to examine the effect of firm size, firm age, solvency ratio, interest rate and growth rate on the performance of stock returns on manufacturing companies. Research data uses financial statements of manufacturing companies listed in Indonesia Stock Exchange as many as $\mathbf{7 7}$ companies as a sample with the research period from 2014-2018. Research method uses hypothesis testing and multiple regression analysis. The results showed that the solvency ratio and growth rate had a positive and significant effect on stock returns. Meanwhile, firm size, firm age and interest rate have no effect on stock returns. Maximizing investor stock returns and company profits can be realized by paying attention to micro and macroeconomic factors in the form of solvency ratio and growth rate
\end{abstract}

Keywords: firm age, firm size, growth rate, interest rate, solvency ratio, and stock return

\section{INTRODUCTION}

Data from Badan Pusat Statistik (BPS) in 2019 recorded that the manufacturing industry in Indonesia contributed 20\% to the national economy. The large market capitalization value of the manufacturing industry sector is a special target for investors in the capital market. The capital market is a forum that bridges investors with companies in investing their capital, and becomes one of the pillars of economic growth. Capital market performance that is running well and is healthy is one of the foundations for the development and economic growth of a country [1].

The capital market is a medium and a means to measure a barometer of a country's economic growth. The capital market provides an instrument to bring together two parties between people or corporate bodies that need funds and other parties who are excess funds [2]. According to [3], many practitioners and academics consider trading volatility on the stock to be a useful technical indicator in measuring market strength because trading in the capital market informs stock market behavior.

The scope and form of a simple investment instrument can be seen from bank savings account holders and to complex forms in the form of investment in bonds, deposits and stocks [4]. Investment decisions taken by investors need a form of careful planning. The initial stage in investment decisions can be done by defining and describing investment ideas, then the second step is carried out by determining the types and variants of investment instruments and finally realizing the ideas and decisions taken [5]. Investing in stocks is a risky decision. Investors need to understand and have sufficient knowledge in the investment field [6]. Research by [7] explain that the disclosure of information for investors and the conditions of the economic climate also affects investors' interest in determining financial planning and investment decisions.

Research by [8] explain that stock return are the return given to investors for investment in a corporate entity traded on the capital market. The returns received by investors are in the form of dividends, capital gains or losses. Stock return is an important element in determining investment decisions for investors. The greater the return generated, the higher the attractiveness of investors [9]. One of the objectives of investors in investing is the desire to obtain maximum return, for that investors should be aware of the factors that also affect the movement of stock performance. Researxh by [10] in their research conducted on non-financial companies listed on the Pakistan Stock Exchange found that there is a relationship between micro and macroeconomic variables on stock return. Micro and macroeconomic factors such as firm age, interest rate are proven to have a positive effect on stock return, while firm size and solvency ratio have no effect on stock return.

Research by [11] argue that the size of the company with large assets does not always contribute to high returns. The size of the company with asset capacity and smooth cash flow is considered to be more able to provide maximum returns.[12] in their research also suggest that the size of the company with a large market capitalization indicates a stronger financial structure, thus obtaining higher investor confidence and a better rate of return. Research by [10] explain that the age of an established company is proven to be able to use their business experience in leading the market, thereby encouraging an increase in company stock returns. Research by [13] suggest that company age plays an important role in stock return performance. Companies with more mature age tend to look for sources of financing to finance their business operations. The debt capital structure is generally taken to gain benefits in the form of a reduction in income tax (interest tax shield) so as to maximize company returns.

[14] explain that a more mature company tends to be more profitable for investors than a company that is still young and has not operated for a long time. [10] argued that the 
determination of the interest rate increase policy has an inverse relationship to stock return. Companies that use a debt financing structure will bear a higher interest expense. This condition causes investors to be more dominant in balancing their portfolios by selling stocks and transferring their funds to investment options which are considered to provide higher returns, thus impacting on the downward trend in stock return.

[15] also suggests that an increase in interest rate causes shocks in the capital market which results in a decrease in stock return, thereby reducing investors' interest in investing in the capital market.

[16] and [17] found that the solvency ratio or leverage plays an important role in stock return. Companies that bear debt that is too high of their total equity are deemed not good for the sustainability of the company, causing concern for their shareholders. Investors do not get the level of compensation at companies with high solvency ratios. A debt burden that is too high causes a decrease in stock returns, which is followed by a shrinkage in the company's profits.

Research by [18] explained that economic growth is the national income of a country which is expressed in the form of GDP (Gross Domestic Product). The increase in economic growth will spur the growth of various lines of economic sectors so that it has an impact on the increase in stock return received by investors. [19] in their research explained growth rate will spur people's purchasing power, this condition causes the company to score higher profits than before, so that an increase in economic growth will increase the return on shares obtained by investors. [10] that an increase in growth rate actually has an impact on stock performance decline because investors will look for investment opportunities that provide higher returns amid increased economic growth.

Indonesia as a member of the G20 which is included in the ranks of largest and influential economies in the world is a special value. The large volume of stock transactions at Indonesia Stock Exchange (IDX) makes IDX a liquid market in Southeast Asia region. Based on previous exposures and this condition, a study entitled Factors Affecting Stock Return of Manufacturing Companies in Indonesia.

\section{LITERATURE REVIEW}

\section{Stock Return}

Investing in shares is a form of investment instrument that is in great demand by capital market players. The large profit factor and high risk that make stocks an investment option that provides high returns for investors [4]. The amount of results obtained is the creation that influences investor interest in investing [20].

Stock return are an important component for market players and financial analysts in determining investment decisions and forecasting market conditions [21] states that investors have a better chance of return if they can analyze macroeconomic components in making investment decisions.

\section{Firm Size}

Research by [22] shows that there is a negative and significant influence between firm size and stock return received by investors. This condition explains that small-scale companies produce more stock return when compared to large companies. Research by [11] shows different results in which there is a positive and significant influence between firm size on stock return. Firm size is considered the main factor that is good in determining the level of stock return. Research conducted by [12] shows positive and significant results between firm size and stock return.

\section{Firm Age}

Research by [23] shows positive results in which there is a significant a nd positive relationship between firm age and stock return. Investment opportunities in mature companies are considered better when compared to companies that are not yet mature. [10] in their research results also show a positive and significant relationship between firm age and stock return. Another study conducted by [13] also states that there is a positive and significant relationship between firm age and stock return. This condition explains that mature companies produce higher stock return when compared to companies that are still ordinary.

\section{Solvency Ratio}

states that the solvency ratio or leverage has a negative relationship with stock return. Large leverage is assessed as the source of the threat to the company's business continuity. Research conducted by [17] also shows the same decision that there is a negative and significant influence between the solvency ratio on stock return. Meanwhile, research by [25] revealed different findings in their research, in which there is a positive and significant relationship between leverage or solvency ratio to stock return. The amount of the company's solvency ratio is considered to have a good impact on the stock performance received by investors.

\section{Interest Rate}

Research conducted by [10] found a negative and significant relationship between interest rate and stock return. High interest rate cause a decrease in stock return. Another study conducted by [26] also found similar results in which there was a significant negative relationship between interest rate and stock returns. Research conducted by [15], [27] also found a negative relationship between interest rates and stock return. The increase in the basis point of interest rate carried out by the central bank through monetary policy causes shocks in the capital market which results in a decrease in stock return.

\section{Growth Rate}

Research by [10] in their research found a negative and significant relationship between economic growth as measured by GDP growth rate and stock returns. The increase in growth rate actually causes a decrease in stock return received by investors. [18] in their research actually found different results in which there was a positive and significant relationship between growth rate and stock return. [28] also state that there is a positive correlation between growth rate and stock return performance. The increase in economic growth will provide higher stock return for investors.METHOD

The research design carried out in this study is a hypothesis testing. The purpose of this study was to ,examine the effect of independent variables, namely firm size, firm age, solvency 
ratio, interest rate and growth rate on the dependent variable, namely stock return. Panel data models contained in panel data regression, namely common effects, fixed effects and random effects. The available data is in the form of financial statements of manufacturing companies listed on the Indonesia Stock Exchange during the period 2014 to 2018 which will then be processed and tested using the e-views 9 software.

TABLE I. VARIABLES AND MEASUREMENTS

\begin{tabular}{|l|l|}
\hline \multicolumn{1}{|c|}{ Variables } & \multicolumn{1}{c|}{ Measurements } \\
\hline Firm Size & Log (Total Assets) \\
\hline Firm Age & No. of Operating Years \\
\hline Solvency Ratio & $\begin{array}{l}\text { Dividing a company's total liabilities by its } \\
\text { shareholder equity }\end{array}$ \\
\hline Interest Rate & Annual interest by government for company \\
\hline Growth Rate & GDP annual growth rate \\
\hline
\end{tabular}

Multiple regression model is statistical technique used in making decisions by estimating the effect of the variables used. The Equation of multiple regression analysis used by this study:

$$
\mathrm{SR}_{\mathrm{it}}=\alpha+\beta_{1} \mathrm{FS}_{\mathrm{it}}+\beta_{2} \mathrm{FA}_{\mathrm{it}}+\beta_{3} \mathrm{SR}_{\mathrm{it}}+\beta_{4} \mathrm{INT}_{\mathrm{it}}+\beta_{5} \mathrm{GR}_{\mathrm{it}}+\mathrm{e}
$$

\section{Keterangan:}

$\mathrm{SR}_{\mathrm{it}}=$ stock return

$\mathrm{FS}_{\mathrm{it}} \quad=$ firm size

$\mathrm{FA}_{\mathrm{it}}=$ firm age

$\mathrm{SR}_{\mathrm{it}}=$ solvency ratio

$\mathrm{INT}_{\text {it }}=$ interest rate

$\mathrm{GR}_{\mathrm{it}}=$ growth rate

\section{RESULT AND DISCUSSION}

Descriptive statistical data testing aims to provide an explanation of the characteristics of the data. Table 2 presents the results of descriptive statistical test in the form of the average value, maximum value, minimum value and standard deviation.

TABLE II. STATISTIC DESCRIPTIVE

\begin{tabular}{|c|c|c|c|c|c|}
\hline Variable & N & Min & Max & Mean & Std. Dev \\
\hline SR & 385 & -0.986359 & 2.594156 & 0.079903 & 0.451462 \\
\hline FS & 385 & 10.60293 & 14.53746 & 12.27259 & 0.705017 \\
\hline FA & 385 & 3.000000 & 37.00000 & 22.37662 & 6.250081 \\
\hline SR & 385 & -5.271743 & 9.554518 & 1.162402 & 1.412297 \\
\hline INT & 385 & 0.042500 & 0.077500 & 0.060500 & 0.014107 \\
\hline GR & 385 & 0.048800 & 0.051700 & 0.050320 & 0.000940 \\
\hline
\end{tabular}

Based on the results of the Eviews 9.0 output that has been obtained, the panel data regression model is suitable for use in hypothesis testing to analyze the factors that affect the stock returns of manufacturing companies in Indonesia, namely the Common Effect Model.

\section{TABLE III. T-TEST RESULT}

\begin{tabular}{|l|c|c|}
\hline \multicolumn{1}{|c|}{ Variables } & Coefficient & Prob. \\
\hline Firm Size & 0.010156 & 0.3364 \\
\hline Firm Age & -0.000420 & 0.7519 \\
\hline Solvency Ratio & 0.014608 & 0.0171 \\
\hline Interest Rate & -1.291173 & 0.4402 \\
\hline Growth Rate & 61.95757 & 0.0094 \\
\hline
\end{tabular}

The test results shows that there is no influence between firm size on stock return. This research is supported by [29] who also found an insignificant relationship between firm size and stock return. Investors do not see the size of the company's total assets as the main factor driving the movement of the company's stock price so that the company's total assets do not affect the amount of stock return. The results showed that investors are more likely to analyze fundamental conditions in the form of price to book value or the ratio of market value to book value as a reference for market players in assessing stock movements and prices rather than analyzing the company's total assets. Research conducted by [30] also obtained similar results that there was no influence between firm size on stock return. Large companies do not always have total assets that come from their own capital, but can also come from borrowed capital which costs interest, so that it has an impact on the company's low stock return performance.

This study shows that there is no influence between firm age on stock return in manufacturing sector companies in Indonesia. This study is not in line with the results of research conducted by [10] which states that there is a positive and significant influence between firm age on stock return. However, this study is supported by [31] who found an insignificant relationship between firm age and stock return. This decision explains that the age of a company is not a determining factor in determining the rate of return on shares. Investors do not view company age as a major factor in determining investment decisions. Established companies and companies that are still young do not affect the rate of stock return, this is because investors are looking at projections of future company performance rather than looking at the age factor of the company. [32] also found similar results where there was no significant effect between firm age on stock return. Young companies with an established company are proven to be able to compete in the market so that investors do not see company size as a dominant factor in driving stock prices so that they do not affect the stock return received by investors.

This research shows that there is a positive and significant influence between the solvency ratio on stock return in manufacturing sector companies in Indonesia. The test result is not in line with the results of research conducted by [10] which states that there is no influence between the solvency ratio on stock return. However, this research is supported by

[24] which states that there is a positive and significant influence between the solvency ratio on stock return. A company with a high debt to equity ratio is proven to be able to provide greater benefits for shareholders, if the company is able to use its debt effectively for the company's business development. Research by [33] also found the same results that there was a positive and significant influence between the solvency ratio on stock return. In addition, [34] also stated that there is a positive and significant influence between the solvency ratio on stock return. This study is in accordance with the MM theory with taxes in which an increase in debt will increase firm value due to tax savings, resulting in a greater stock return.

The test result shows that there is no influence between interest rate on stock return in manufacturing sector companies in Indonesia. This research is supported by [35] which states that there is no significant effect between interest rate on stock return. Interest rate are considered not to have a long-term impact on the company's operations so that they do not affect the company's 
stock performance. [36] also stated that interest rate have no effect on stock return. The contractionary monetary policy through the increase and decrease in interest rates does not have a long-term effect on stock return performance. Research conducted by [37] also found similar results that there was no influence between interest rates on stock return. Investment decisions also involve psychological factors by the investors themselves, so that the theory of the impact of interest rate policies on stock return is not always proven.

This study shows that there is a positive and significant influence between growth rate on stock return. This condition explains that the growth rate of GDP (Gross Domestic Product) in a country affects the increase in stock return. This study is not in line with the results conducted by [10] which states that there is a negative and significant effect between growth rate on stock return. This condition explains that the increase in growth rate causes a decrease in prices on the stock market, thus reducing stock return. This study is in line with [19] that there is a positive influence between growth rate and stock return. This reason is based on the fact that increasing GDP means that people's purchasing power increases. With the increase in purchasing power, the company will score higher profits, thereby increasing the company's stock price. Growth rate also drives the rate of growth on the financial market so that it correlates with investors in the capital market. Another research conducted by [38] also got positive and significant results between growth rate and stock return. This study is based on the correlation between growth rate and stock returns showing a dynamic joint movement. High economic growth with low economic risk volatility will have a positive effect on stock market performance, which is indicated by the increase in stock return received by investors.

\section{CONCLUSION}

This study aims to determine the effect of the independent variables, namely firm size, firm age, solvency ratio, interest rate and growth rate on the dependent variable stock return in 77 manufacturing companies listed on the Indonesia Stock Exchange in 2014-2018, it can be concluded that firm size, firm age, interest rate have no effect on stock returns, while the solvency ratio and growth rate have a positive and significant effect on stock return. Suggestions that can be given to further researchers are adding influencing variables such as price earning ratio.

\section{REFERENCES}

[1] H. Zhao, "Dynamic relationship between exchange rate and stock price: Evidence from China," Res. Int. Bus. Financ., vol. 24, no. 2, pp. $103-112,2010$

[2] A. Srivastava, "Relevance of Macro Economic factors for the Indian Stock Market,” Decision, vol. 37, no. 3, pp. 69-89, 2010.

[3] H. Al Samman and M. K. Al-Jafari, "Trading volume and stock returns volatility: Evidence from industrial firms of Oman," Asian Soc. Sci., vol. 11, no. 24, pp. 139-146, 2015.

[4] S. Arora and K. Marwaha, "Variables influencing preferences for stocks (high risk investment) vis-à-vis fixed deposits (low-risk investment): A comparative study," Int. J. Law Manag., vol. 56, no. 4, pp. 333-343, 2014.

[5] A. Puška, A. Beganovic, and S. Šadic, "Model for investment decision making by applying the multi-criteria analysis method,' Serbian J. Manag., vol. 13, no. 1, pp. 7-28, 2018.

[6] G. Kabra, P. K. Mishra, and M. K. Dash, "Factors Influencing Investment Decision of Generations in India: An Econometric Study," Asian J. Manag. Res., vol. 1, no. 1, pp. 308-326, 2010.

[7] M. S. Ebenezer, Bennet, I. Tiruchirappalli, and R. Rajesh, "Factors Influencing Retail Investors' Attitude Towards Investing in Equity Stocks: A Study in Tamil Nadu," J. Mod. Account. Audit., vol. 7, no. 3, pp. 316-321, 2011.

[8] C. J. ZUTTER and B. S. SCOTT, "Principles of Managerial Finance, 15th Edition. United States: Pearson Education Limited.," 15th Editi., Pearson Education Limited, Ed. United States: Pearson Education Limited, 2019.

[9] A. Saeedi and M. Ebrahimi, "The role of accruals and cash flows in explaining stock returns: Evidence from Iranian companies," Int Rev. Bus. Res. Pap., vol. 6, no. 2, pp. 164-179, 2010.

[10] K. Abbass, H. Song, S. Shah, and B. Aziz, "Determinants of Stock Return for Non-Financial Sector: Evidence from Energy Sector of Pakistan,” J. Bus. Financ. Aff., vol. 8, no. 1, pp. 1-9, 2019.

[11] K. Hou and M. A. Van Dijk, "Resurrecting the size effect: Firm size profitability shocks, and expected stock returns," Rev. Financ. Stud., vol. 32, no. 7, pp. 2850-2889, 2019.

[12] B. W. Mazviona and D. Nyangara, "Does firm size affect stock returns? Evidence from the Zimbabwe Stock Exchange.," Int. J. Bus. Econ. Dev., vol. 2, no. 3, pp. 13-17, 2014.

[13] B. T. Matemilola, A. N. Bany-Ariffin, A. M. Nassir, and W. N. W. Azman-Saini, "Moderating Effects of Firm Age on the Relationship between Debt and Stock Returns," J. Asia-Pacific Bus., vol. 18, no. 1, pp. 81-96, 2017.

[14] G. Agiomirgianakis, A. Magoutas, and G. Sfakianakis, "Determinants of Profitability in the Greek Tourism Sector Revisited: The Impact of the Economic Crisis," J. Tour. Hosp. Manag., vol. 1, no. 1, pp. 57-59, 2013.

[15] S. Al Oshaibat, "The relationship between stock returns and each of inflation, interest rates, share liquidity and remittances of workers in the Amman stock exchange," J. Internet Bank. Commer., vol. 21, no. $2,2016$.

[16] M. N. Abdullah, K. Parvez, T. Karim, and R. B. Toohen, "The Impact of Financial Leverage and Market Size on Stock Returns on the Dhaka Stock Exchange: Evidence from Selected Stocks in the Manufacturing Sector," Int. J. Econ. Financ. Manag. Sci., vol. 3, no. 1 , pp. 10-15, 2015.

[17] M. Andersson, "The Effect of Leverage on StockReturns," 2016.

[18] P. Mladina and S. Germani, "The Enigma of Economic Growth and Stock Market Returns," in Northern Trust, 2016, pp. 1-4.

[19] G. SAYAR ÖZKAN, Y. E. AKBAȘ, and M. SENTÜRK, "The Relationship Between Economic Growth and Stock Returns: Evidence From Turkey," Doğus Üniversitesi Derg., vol. 2, no. 15, pp. 155-164, 2014.

[20] F. Zareian and H. Krawinkler, "Conceptual performance-based seismic design using building-level and story-level decision support system," Earthq. Eng. Struct. Dyn., vol. 41, no. 11, pp. 1439-1453, 2012.

[21] M. Shakeel and A. Gohar, "The Relationship Between Fundamental Analysis and Stock Returns Based on the Panel Data Analysis; Evidence from Karachi Stock exchange (KSE)," Res. J. Financ. Account., vol. 9, no. 3, pp. 84-96, 2018.

[22] N. T. Duy and N. P. Huu Phuoc, "The Relationship between Firm Sizes and Stock Returns of Service Sector in Ho Chi Minh City Stock Exchange," Rev. Eur. Stud., vol. 8, no. 4, p. 210, 2016.

[23] Y. Awudu, S. Sampson, and V. Esumanba, "Determinants of Abnormal Returns on the Ghana Stock Exchange," vol. 4, no. 11, pp. 7-17, 2013.

[24] M. Nayeem, K. Parvez, T. Karim, and R. B. Toohen, "The Impact of Financial Leverage and Market Size on Stock Returns on the Dhaka Stock Exchange: Evidence from Selected Stocks in the Manufacturing Sector," Int. J. Econ. Financ. Manag. Sci., vol. 3, no. 1, pp. 10-15, 2015. 
[25] W. Khan, A. Naz, M. Khan, W. K. Q. Khan, and S. Ahmad, "The Impact of Capital Structure and Financial Performance on Stock Returns 'A Case of Pakistan Textile Industry," Middle East J. Sci. Res., vol. 16, no. 2, pp. 289-295, 2013.

[26] A. M. Benigno, Relationships Between Interest Rate Changes and Stock Returns: International Evidence Using a Quantile-on-Quantile Approach. 2016.

[27] E. Sebnem and B. Vuran, "Factors Affecting Stock Returns of Firms Quoted in ISE Market: A Dynamic Panel Data Approach," Factors Affect. Stock Returns Firms Quoted ISE Mark. A Dyn. Panel Data Approach, vol. 2, no. 1, pp. 108-121, 2012.

[28] X. Hua et al., "Brain growth rate abnormalities visualized in adolescents with autism," Hum. Brain Mapp., vol. 34, no. 2, pp. 425436, 2013.

[29] J. A. Ayuba, G. S. Balago, and D. Y. Dagwom, "Effects of Macroeconomic Factors on Stock Returns in Nigeria," Int. J. Financ. Account., vol. 7, no. 4, pp. 122-131, 2018.

[30] S. Shabib-ul-hasan, S. Farooq, and M. Muddassir, "Stock Returns Indicators: Debt to Equity, Book to Market, Firm Size and Sales to Price," J. Poverty, Invest. Dev., vol. 16, pp. 25-32, 2015.

[31] A. A. Dabar, "Relationship Between Fixed Capital Investment and Stock Returns of Firms Listed At the Nairobi Securities Exchange," UNIVERSITY OF NAIROBI, 2018.

[32] F. Khan, S. U. R. Khan, and H. Khan, "Pricing of risk, various volatility dynamics and macroeconomic exposure of firm returns: New evidence on age effect," Int. J. Econ. Financ. Issues, vol. 6, no. 2, pp. 551-561, 2016.

[33] M. Aloui and A. Jarboui, "The effects of corporate governance on the stock return volatility: During the financial crisis," Int. J. Law Manag., vol. 60, no. 2, pp. 478-495, 2018.

[34] W. U. Din, "Stock Return Predictability with Financial Ratios: Evidence from PSX 100 Index Companies," SSRN Electron. J., no. january, pp. 1-15, 2017.

[35] T. Olweny and K. Omondi, "The Effect of Macro-Economic Fctors on Stock rReturn Volatility in the Nairobi Stock Exchange, Kenya," Econ. Financ. Rev., vol. 1, no. 10, pp. 34-48, 2011.

[36] A. Hussain, G. Zaman, and Q. B. Baloch, "The Causal Relationship of Interest Rate and Stock Prices: Empirical Evidence From Pakistani. The Causal Relationship of Interest," Causal Relatsh. Interes. Rate Stock Prices Empir. Evid. From Pakistani, vol. 4, no. 2, pp. 147-155, 2014.

[37] Z. Zakaria, J. Muhammed, and A. H. Zulkifli, "The impact of dividend policy on the share price volatility: Malaysian Construction and Material Compa

[38] nies,” Int. J. Econ. Manag. Sci., vol. 2, no. 5, pp. 01- 08, 2012.J. Yu, "Dynamics in the co-movement of economic growth and stock return: comparison between the United States and China," Econ. Res. Istraz., vol. 32, no. 1, pp. 1965-1976, 2019. 